Available Online at SAINS TANAH Website: http://jurnal.uns.ac.id/tanah

SAINS TANAH - Journal of Soil Science and Agroclimatology, 16(1) , 2019, 90-102

RESEARCH ARTICLE

\title{
REMEDIATION OF CHROMIUM CONTAMINATED SOIL BY PHYTO-BIO SYSTEM (PBS) APPLICATION
}

\author{
Retno Rosariastuti , Selly Maisyarah, Sudadi, Sri Hartati, and Purwanto \\ Department of Soil Science, Faculty of Agriculture, Sebelas Maret University, Surakarta \\ Submitted: 2018-10-30 Accepted: 2019-06-21
}

\begin{abstract}
Chromium polluted water was increased as the result of the growth of the industries, due to their industrial waste were most likely contain heavy metals, especially textile industrial waste that was discarded to the rivers. This research aimed to study the removal of chromium levels in soil used the symbiosis between plant and bacteria. Soil sample contained with $4.33 \mathrm{mg} \mathrm{kg}^{-1}$ and the irrigation water sample contained with $1.09 \mathrm{mg} \mathrm{l}^{-1}$ of total chromium. This research design was factorial with Randomized Complete Block Design as the based design There were 3 factors in this study: 1 . inorganic fertilizer (P): P0: without inorganic fertilizer, P1: with inorganic fertilizer; 2 . chelator (B):B0: without chelator, B1: with chelator Rhizobium sp I3, B2: with chelator manure; 3. Plant (T): T0 without plant, T1: with plant. Data were analyzed by statistical analysis using ANOVA continued by T-test or Duncan Multiple Range test and correlation test. The result showed that the remediation process reduced chromium levels in soil with the removal effectivity up to $71.90 \%$ on the treatment combination of NPK fertilizer+manure+plant while removal effectivity on plant-only treatment was $55.66 \%$. The chromium levels in Fimbristylis globulosa were in the range from 1.82-3.15 $\mu^{-1}$, it indicated that Fimbristylis globulosa was a feasible plant for bioremediation. Fimbristylis globulosa grew well and has the ability to absorb chromium, especially by combining it with Rhizobium sp $I_{3}$ and the chromium uptake in roots was higher than shoots.
\end{abstract}

Keywords: Industrial waste, Manure, Phytoremediation, Rhizobium sp /3, Rhizoremediation

How to Cite: Rosariastuti, R., Maisyarah, S., Sudadi, Hartati, S., and Purwanto. (2019). Remediation of Chromium Contaminated Soil by Phyto-Bio System (PBS) Application. Sains Tanah Journal of Soil Science and Agroclimatology, 16(1): 90-102 (doi: 10.20961/stjssa.v16i1.24932)

Permalink/DOI: http://dx.doi.org/10.20961/stjssa.v16i1.24932

\section{INTRODUCTION}

The waste produced from anthropogenic activity such as industries has become a big threat in health for humans, animals, and plants. Industries, especially textile industries around the paddy fields used for this study discarded their waste to the river where farmers used the river as the main irrigation source, thus led to soil contamination.

\footnotetext{
* Corresponding Author : Email: retnobs@staff.uns.ac.id
}

According to the Indonesian Ministry of Environment (2010), the textile industry produced waste containing heavy metals, such as chromium. Chromium found in various industrial activities such as textile, wood preservation, iron coating and tanning (Ferina et al., 2017). Heavy metals tend to be accumulated in the food chain and it may cause several health problems if consumed by human and accumulated in the human body. In the environment, chromium usually encountered a reduction state of hexavalent chromium (VI) 
and trivalent chromium (III) (Silva et al., 2008). Hexavalent chromium (VI) has mutagenicity, teratogenicity, carcinogenicity properties and has high solubility and mobility which is very toxic to the living system while trivalent chromium (III) is less harmful, less mobile and less soluble in water (Pramono et al., 2012; Pramono et al., 2013). According to Lattanzi et al. (2015), hexavalent chromium (VI) is an easily mobilized trace element and not capable of being retained by soil constituents, also readily absorbed by plants due to its high mobility in the soil environment.

Looking at the consequence of chromium contamination, remediation is indispensable. Remediation could be done by conventional methods consisting of a chemical and physical process but these applications were less effective and costly. The remediation technique selected for this study were phytoremediation (use Fimbristylis globulosa) and bioremediation with a microorganism (used Rhizobium sp / $I_{3}$ ). Phytoremediation was the use of plants to control or cleanup many kinds of pollutants including oil, pesticides, and metals (Zhang et al., 2010). Bioremediation is a microbiological activity that applied to transform contaminants to less toxic or nontoxic forms, instead of just collecting and storing pollutants (Abatenh et al., 2017).

Fimbristylis globulosa in Indonesia known as Mendong plant belonged to Cyperaceae family and grows in the flooded area and commonly used as cane work with the product such as hat and basket, mostly cultivated in Sumatra and Java. Fimbristylis globulosa According to (Ferina et al., 2017) a plant could be used as hyperaccumulator plant up to standard has the ability to do phytoextraction of heavy metal, rapid growth, high durability, and it is a non-food plant.
This study used Rhizobium $s p I_{3}$ as a bioremediator which is also a chelator because based on (Rosariastuti, 2014), Rhizobium sp I 3 was able to increase the dry weight of plant and chromium uptake in shoot and root effectively by two-fold. Manure was used as a chelator because manure consists of complex organic matter compound that could reduce the $\mathrm{Cr}(\mathrm{VI})$ become $\mathrm{Cr}(\mathrm{III})$ leading to less toxic chromium levels in soil and simple organic matter compound that could increase the $\mathrm{Cr}$ mobility. NPK fertilizer also used in this study to maintain nutrition requirement of Fimbristylis globulosa and to know the contribution of NPK fertilizer in increasing the chromium levels in the soil. NPK fertilizer, chelator (Rhizobium sp $I_{3}$ or manure) and Fimbristylis globulosa were all combined to study which of the combination was the best in increasing chromium uptake by Fimbristylis globulosa and reducing total chromium levels in the soil.

\section{MATERIAL AND METHODS}

This study conducted from May to November 2017 in chromium contaminated paddy fields located in Waru village, Kebakkramat sub-district, Karanganyar regency of Central Java Province. This research design was factorial with Randomized Complete Block Design as the based design There were 3 factors in this study: 1 . inorganic fertilizer (P) : P0: without inorganic fertilizer, $\mathrm{P}$ 1: with inorganic fertilizer; 2 . chelator (B): $\mathrm{B} 0$ : without chelator, B1: with chelator Rhizobium $s p I_{3}, \mathrm{~B} 2$ : with chelator manure; 3. Plant (T): T0 without a plant, $\mathrm{T} 1$ : with plant. All three factors were combined resulting in 12 treatment combinations (table 1) and every treatment combination were repeated three times which means there are unit treatments. 
Table 1. Treatment combinations

\begin{tabular}{ll}
\hline Treatment & \multicolumn{1}{c}{ Meaning } \\
\hline POBOT0 & without NPK fertilizer; without chelator; without plant \\
POB1T0 & without NPK fertilizer; with chelator Rhizobium $s p I_{3} ;$ without plant \\
POB2T0 & without NPK fertilizer; with chelator manure; without plant \\
P1B0T0 & with NPK fertilizer; without chelator; without plant \\
P1B1T0 & with NPK fertilizer; with chelator Rhizobium $s p I_{3}$; without plant \\
P1B2T0 & with NPK fertilizer; with chelator manure; without plant \\
POBOT1 & without NPK fertilizer; without chelator; with plant \\
POB1T1 & without NPK fertilizer; with chelator Rhizobium $s p I_{3} ;$ with plant \\
POB2T1 & without NPK fertilizer; with chelator manure; with plant \\
P1B0T1 & with NPK fertilizer; without chelator; with plant \\
P1B1T1 & with NPK fertilizer; with chelator Rhizobium $s p I_{3} ;$ with plant \\
P1B2T1 & with NPK fertilizer; with chelator manure; with plant \\
\hline
\end{tabular}

\section{Land preparation}

The land preparation began with cleaned off weeds and 36 plots were made in size of $2.5 \mathrm{~m} \times 2.5 \mathrm{~m}$ which every plot consisting 25 subplots with the size $50 \mathrm{~cm} \times 50 \mathrm{~cm}$ for the space between plants and $25 \mathrm{~cm}$ for the space of the edge.

\section{Chelator and NPK fertilizer preparation}

Rhizobium $\mathrm{sp} I_{3}$ inoculum preparation began with grew isolates in tilting media of Luria Bertani (LB) agar continued by making the starter with the isolates in $100 \mathrm{ml}$ of Luria Bertani (LB) liquid medium (10 g tripton, $5 \mathrm{~g}$ yeast extract, $10 \mathrm{~g} \mathrm{NaCl}$ and $100 \mathrm{~mL}$ distilled water). The starter shook for three days and being scaled up to larger LB liquid medium (900 $\mathrm{ml}$ ). The whole medium shook until its cell density got up to $10^{9} \mathrm{cfu} \mathrm{ml}^{-1}$ (observed the morphology) and applied with the dose per subplot $5 \times 10^{9}$ cell g-1 of soil (by multiplied $10^{5}$ cell $\mathrm{ml}^{-1}$ (desired amount of Rhizobium sp $\mathrm{I}_{3}$ in soil) to bulk density $\left(5 \times 10^{4}\right)$. According to Adji (2006), the right dose of manure for Fimbristylis globulosa was 5 ton ha ${ }^{-1}$ and based on Darini (2012), the dose of NPK fertilizer for Fimbristylis globulosa was $400 \mathrm{~kg} \mathrm{ha}^{-1}$. After being calculated to the dose of plots $(2.5 \mathrm{~m} x$ $2.5 \mathrm{~m}=6.25 \mathrm{~m}^{2}$ ) the dose for manure was 3.125 $\mathrm{g} \mathrm{plot}^{-1}$ and for NPK fertilizer was $81.25 \mathrm{~g} \mathrm{plot}^{-1}$ of Urea, $103.75 \mathrm{~g} \mathrm{plot}^{-1}$ of SP-36 and $62.5 \mathrm{~g} \mathrm{plot}^{-}$ ${ }^{1}$ of $\mathrm{KCl}$.

\section{Application until analysis}

Rhizobium $s p I_{3}$ and manure were applied one week before planting, Fimbristylis globulosa were planted on the prepared plots, and NPK fertilizer applied one day after planting. After two months, Fimbristylis globulosa were harvested and analyzed. The analysis of soil parameters include $\mathrm{pH} \mathrm{H}_{2} \mathrm{O}$ (Electrometric), Cation Exchange Capacity (CEC) (ammonium acetate saturation), C Organic (Walkley and Black), and total Rhizobium sp $I_{3}$ colony (plate count). Chromium analysis in the soil, water dan plant tissue carried out using wet destruction (analysis of total chromium). Removal effectivity (\%) was calculated by $=[($ initial concentration-final concentration)/initial concentration] $\times 100 \%$. Data were analyzed by statistical analysis using ANOVA continued by T-test or Duncan Multiple Range test also correlation test. 
Table 2. Final Soil Characteristics

\begin{tabular}{|c|c|c|c|c|c|}
\hline No. & Treatment* & pH & CEC (cmol(+) kg-1) & Organic Matter (\%) & $\begin{array}{l}\text { Total Rhizobium sp / } 3 \\
\quad\left(\log _{10} \mathrm{CFU} \mathrm{g}^{-1}\right)\end{array}$ \\
\hline 1. & РОВОТО & 6.54 & $28.6 a$ & $4.30 a$ & 12.93 \\
\hline 2. & Р0B1T0 & 6.74 & $33.6 \mathrm{bc}$ & 4.45ab & 13.25 \\
\hline 3. & РОВ2ТО & 6.72 & $43.6 \mathrm{~d}$ & $4.83 c d$ & 13.20 \\
\hline 4. & Р1В0T0 & 6.65 & $32.8 b$ & $4.65 b c$ & 12.97 \\
\hline 5. & P1B1T0 & 6.67 & $34.4 \mathrm{bc}$ & $4.63 b c$ & 13.33 \\
\hline 6. & Р1В2T0 & 6.71 & 44.8de & $4.65 b c$ & 13.14 \\
\hline 7. & РОВ0T1 & 6.71 & $37.6 c$ & $4.56 a b c$ & 13.11 \\
\hline 8. & P0B1T1 & 6.78 & $33.3 b c$ & $4.70 b c$ & 13.30 \\
\hline 9. & Р0В2Т1 & 6.77 & 48.4ef & $5.08 \mathrm{de}$ & 13.22 \\
\hline 10. & P1B0T1 & 6.76 & $36.5 b c$ & 4.41ab & 13.17 \\
\hline 11. & P1B1T1 & 6.73 & $42.8 d$ & 4.59abc & 13.45 \\
\hline 12. & P1B2T1 & 6.82 & $51.2 f$ & $5.24 \mathrm{e}$ & 13.31 \\
\hline
\end{tabular}

Note: Mean followed with the same letter in the same column is not significantly different at $\alpha=0.05$; ${ }^{*}$ ) Table 1

\section{RESULTS}

\section{Initial soil characteristic}

The soil ordo in the area where this study conducted was categorized as Vertisol based on soil classification of USDA stated in Statistics of Karanganyar Regency (2011). The analysis showed that soil pH 6.22 (slightly acid), soil CEC $25.27 \mathrm{cmol} \mathrm{kg}^{-1}$ (very low), organic matter $2.73 \%$ (low), the total population of Rhizobium sp $I_{3} 11.72 \mathrm{Log}_{10} \mathrm{CFU} \mathrm{g}^{-1}$ and total chromium level in soil $4.33 \mathrm{mg} \mathrm{kg}^{-1}$ exceeded the $2.3 \mathrm{ppm}$ standard stated by Indonesian Ministry of Environment (2010).

\section{Final soil characteristic after the remediation process}

Treatment application increased soil $\mathrm{pH}$, soil CEC, soil organic matter, and total Rhizobium sp $I_{3}$ colony. The result of the analysis showed in table 2. ANOVA showed that the plant had a significant effect $(p<0.05)$ to increased soil $\mathrm{pH}$ and other treatment interaction did not significantly affect soil $\mathrm{pH}$. T-test showed that $\mathrm{pH}$ was higher on $\mathrm{T} 1$ than T0. Correlation test showed that soil $\mathrm{pH}$ was positively and closely correlated with plant height ( $r=0.648 \mathrm{p}=0.04)$. Increased $\mathrm{pH}$ value led to increased plant height.
ANOVA showed that NPK fertilizer treatment, chelator treatment, plant treatment and interaction of NPK fertilizer + chelator + plant treatment had a significant effect $(p<0.05)$ to soil CEC. T-test showed CEC was higher on P1 and T1 than P0 and T0. DMR test showed that $C E C$ was higher on $B 2$ than $B 0$ and B1. DMR test on the interaction of NPK fertilizer + chelator + plant showed that the treatment of P1B2T1 (NPK fertilizer+ manure+ plant) had the highest CEC compared to other treatments. Correlation test showed that CEC was positively and closely correlated to organic matter $(r=0.711 p=0.01)$, plant height $(r=0.517$ $p=0.028)$, and the number of tillers per clump $(r=0.660 p=0.003)$. Higher soil CEC led to increased organic matter, plant height and number of tillers.

ANOVA showed that the treatment of chelator, plant, chelator + plant interaction and fertilizer + chelator + plant interaction had a significant effect $(p<0.05)$ to soil organic matter. A t-test on a plant showed that soil organic matter was higher on T1 than TO. DMR test of the treatment of chelator, chelator + plant interaction and fertilizer + chelator + plant interaction showed that B2, B2T1, and P1B2T1 had the highest organic matter compared to other treatments. Organic matter 
positively and closely correlates with CEC $(r=0.711 p=0.001)$. That means the increased of organic matter led to increased soil CEC. ANOVA showed that chelator treatment and plant treatment had a significant effect $(p<0.05)$ on Rhizobium sp l 3 population. DMR test on chelator showed that the highest Rhizobium $s p I_{3}$ population were found in B1. The t-test shows that $\mathrm{T} 1$ had higher Rhizobium sp $I_{3}$ population than TO. Correlation test showed that the Rhizobium sp $I_{3}$ population positively and quite closely correlated with the chromium levels in the roots $(r=0.471$ $\mathrm{p}=0.048)$. The higher Rhizobium $s p \quad I_{3}$ population could increase chromium levels in the roots.

\section{Total chromium levels in the soil}

Chromium levels in soil decreased after the remediation process (initial chromium level in soil was $4.33 \mathrm{mg} \mathrm{kg}^{-1}$ ). Chromium levels in all treatments presented in Figure 1. Based on ANOVA, plant treatment, fertilizer + plant interaction, and chelator + plant interaction had a significant effect $(p<0.05)$ to chromium levels on the soil. T-test showed that the chromium level in soil was lower on $\mathrm{T} 1$ than T0, presented in Figure 2. The DMR test on fertilizer+plant interaction showed that P1T1 gave the best effect with low chromium levels in the soil, presented in Figure 3.

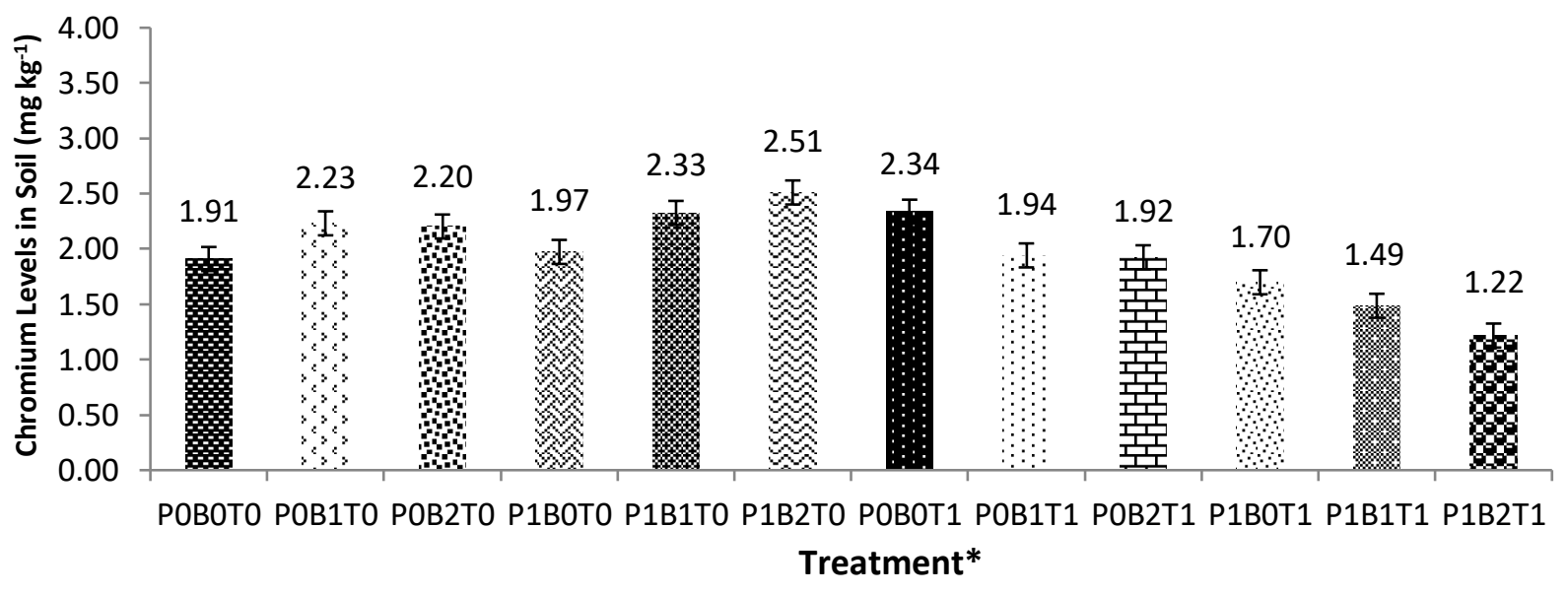

Figure 1. Effect of NPK fertilizer, chelator, and plant on chromium levels in soil Note: ${ }^{*}$ ) Table 1

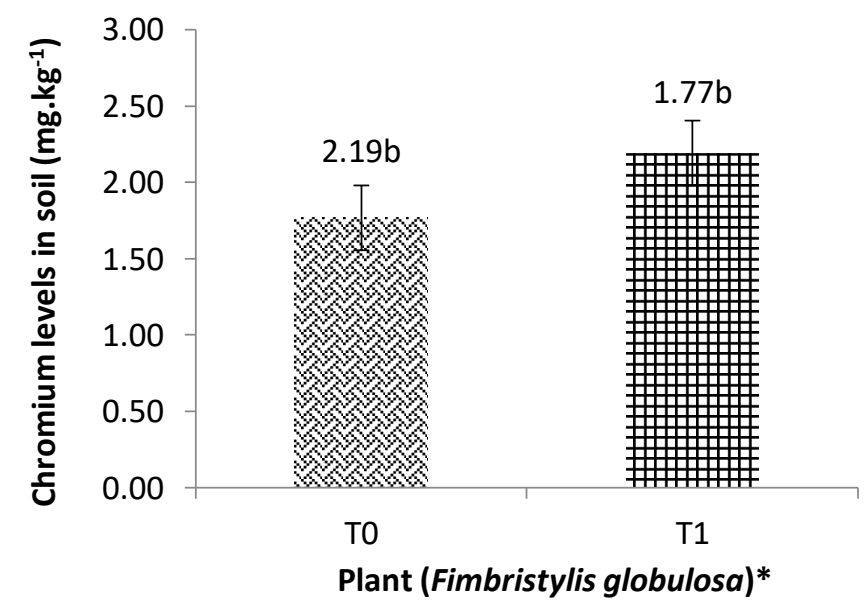

Figure 2. Effect of Fimbristylis globulosa on chromium levels in soil Note: Mean followed with the same letter in the same column is not significantly different at $\alpha=0.05 ;{ }^{*}$ ) Table 1 


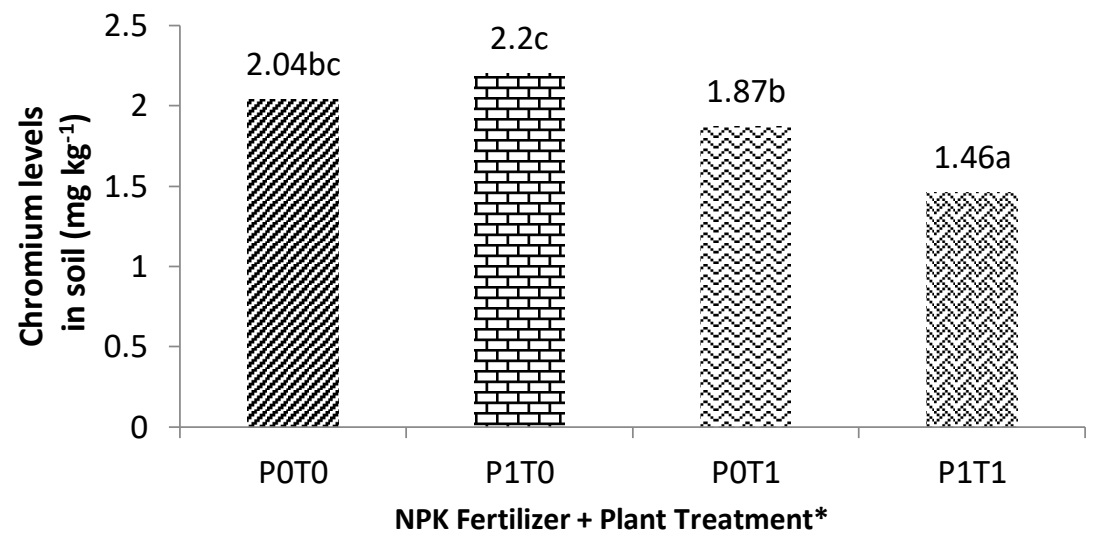

Figure 3. Effect of NPK fertilizer + plant treatment interaction on chromium levels in soil Note: Mean followed with the same letter in the same column is not significantly different at $\alpha=0.05$; *) Table 1

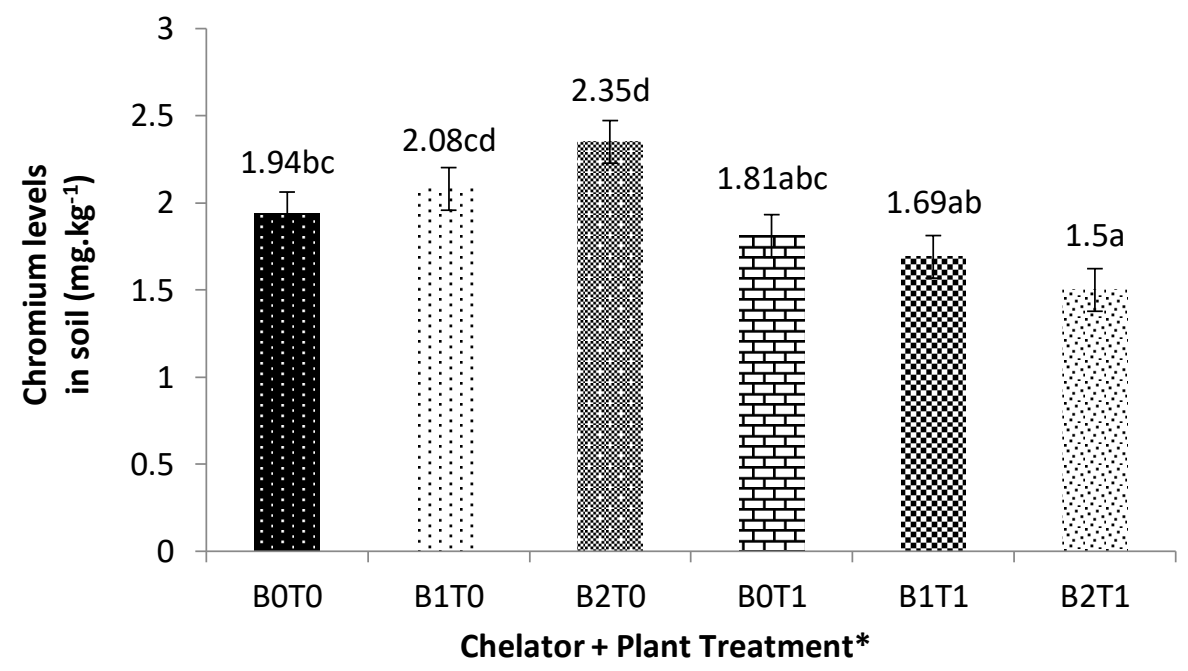

Figure 4. Effect of chelator + plant treatment interaction on chromium levels in soil Note: Mean followed with the same letter in the same column is not significantly different at $\alpha=0.05 ;{ }^{*}$ ) Table 1

DMR test showed that B2T1 had the lowest levels of chromium in soil and significantly different from other treatment interaction, presented in Figure 4. Correlation test showed that chromium levels in the soil negatively and closely correlated with chromium uptake at roots $(r=-0.600 p=0.009)$ total chromium uptake in plants $(r=-0.610$ $p=0.007)$ and very closely correlated to removal effectivity $(r=-1.000 p=0.000)$. That means chromium uptake in plant increased, especially at the root that led to decreased levels of chromium in soil, so that the removal effectivity increased.

\section{Removal effectivity}

Removal effectivity showed the change of initial chromium levels in the soil $(4.33 \mathrm{mg}$ $\mathrm{kg}^{-1}$ ) to the result after the remediation process. Results presented in Figure 5. 


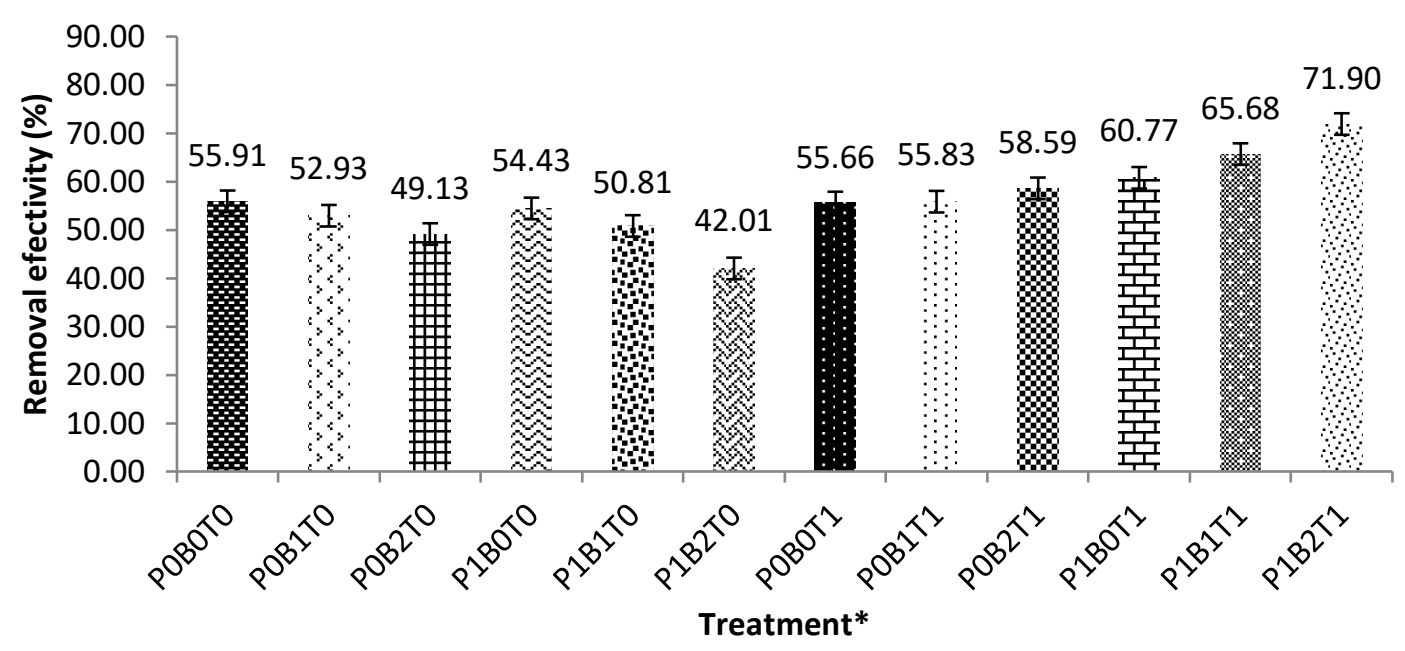

Figure 5. Effect of NPK fertilizer, chelator, and plant on removal effectivity Note: ${ }^{*}$ ) Table 1

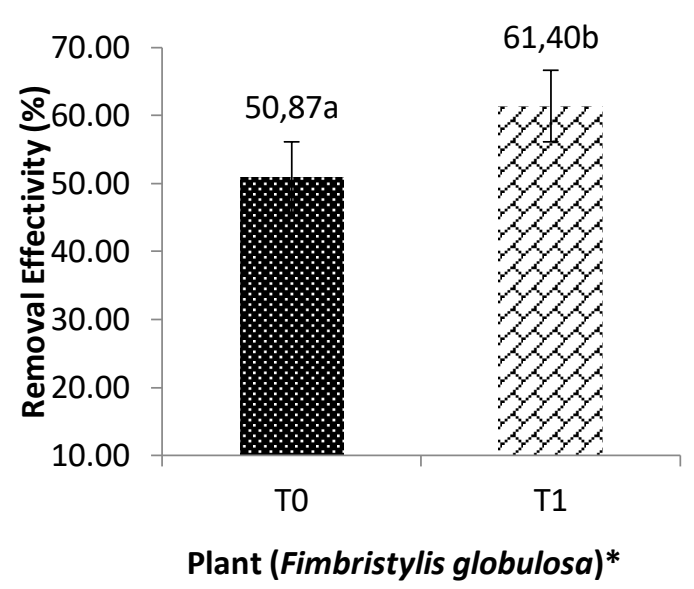

Figure 6. Effect of Fimbristylis globulosa on removal effectivity

Note: Mean followed with the same letter in the same column is not significantly different at $\alpha=0.05$; *) Table 1

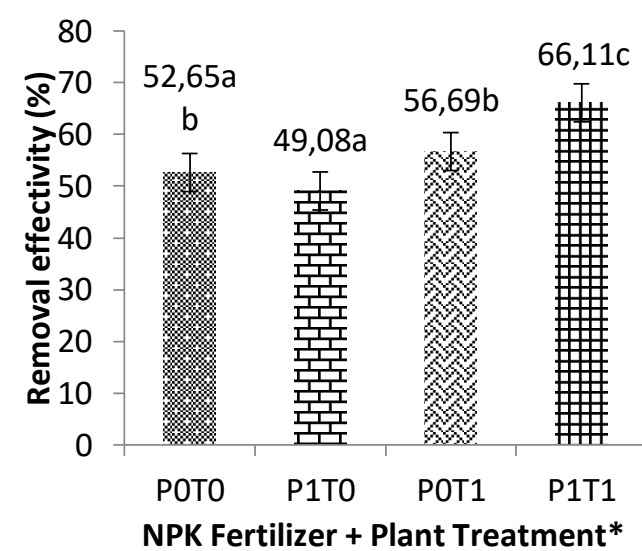

Figure 7. Effect of NPK fertilizer + plant treatment interaction on removal effectivity

Note: Mean followed with the same letter in the same column is not significantly different at $\alpha=0.05 ;{ }^{*}$ ) Table 1

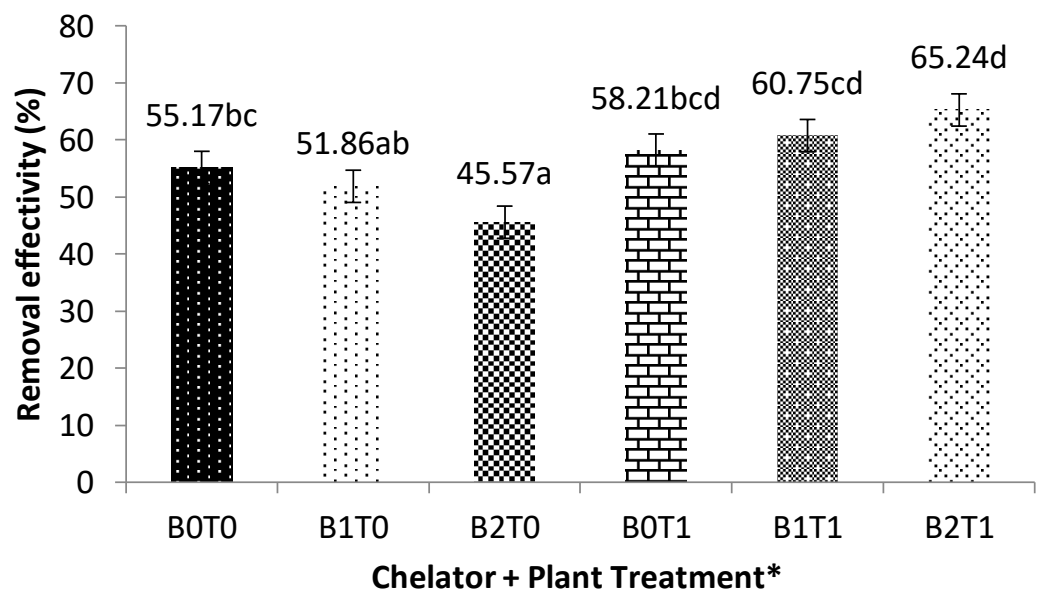

Figure 8. Effect of NPK fertilizer + plant treatment interaction on removal effectivity Note: Mean followed with the same letter in the same column is not significantly different at $\alpha=0.05 ;{ }^{*}$ ) Table 1 


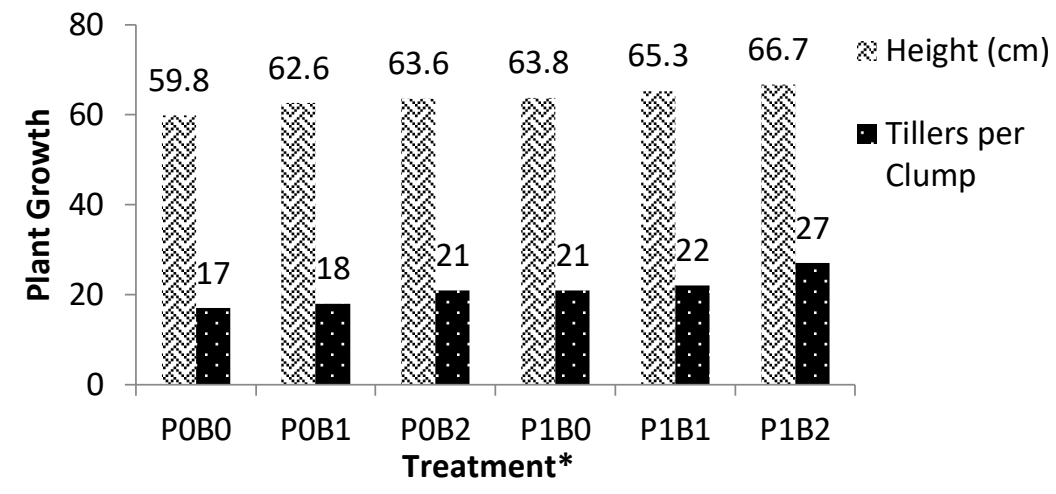

Figure 9. Effect of NPK fertilizer and chelator on plant height and number of tillers per clump Note: *) Table 1

ANOVA showed that plant treatment, the interaction of NPK fertilizer+plant, and interaction of chelator+plant had a significant effect $(p<0.05)$ on the removal effectivity. Based on the T-test, T1 was more effective than T0, presented in Figure 6. Fimbristylis globulosa absorbed chromium from the soil and increased the removal effectivity. DMR test on the interaction of NPK fertilizer+plant showed that the highest removal effectivity was on P1T1, presented in Figure 7. The DMR test on the interaction of chelator+plant showed that B2T1 treatment had the highest removal effectivity compared to other treatments, presented in Figure 8.

Removal effectivity positively and closely correlated with chromium uptake at root $(r=0.598 p=0.009)$ and total chromium absorption in plant $(r=0.608 p=0.007)$, also negatively and closely correlated to chromium level in soil $(r=-1.000 p=0.000)$. The increased total absorption in plants, especially at the root led to increased removal effectivity by decreasing chromium levels in soil.

\section{Agronomical Character of Fimbristylis globulosa \\ Plant growth}

The height at the maximum vegetative period and number of tillers per clump, effect of treatments to the height and number of tillers per clump of Fimbristylis globulosa presented in Figure 9. ANOVA showed that the application of NPK fertilizer gave a significant effect $(p<0.05)$ to the plant height. T-test showed that plant height was higher on P1 than P0. Correlation test showed that plant height was positively correlated with the dry weight of the plant $(r=0.583 p=0.011)$. That means the increasing plant height increased the dry weight of the plant. ANOVA showed that NPK fertilizer treatment and chelator treatment have a significant effect $(p<0.05)$ on the number of tillers per clump. T-test showed that $P 1$ had a higher average number of tillers than P0. DMR test on chelator showed that B2 had the highest average number of tillers compared to B0 and B1.

Correlation test showed that the number of tillers per clump positively and very closely correlated to chromium uptake in the roots $(r=0.868 p=0.000)$, total chromium uptake in plants $(r=0.868 p=0.000)$, dry weight of root $(r=0.835 p=0.000)$, dry weight of total plant $(r=0.855 p=0.000)$, also closely correlated to removal effectivity $(r=0.570 p=0.014)$ and dry weight of shoot $(r=0.623 \quad p=0.006)$ and negatively and closely correlated to chromium levels in the soil ( $r=-571 p=0.013)$, which means that the higher number of tillers per clump led to the increased dry weight and chromium uptake. 


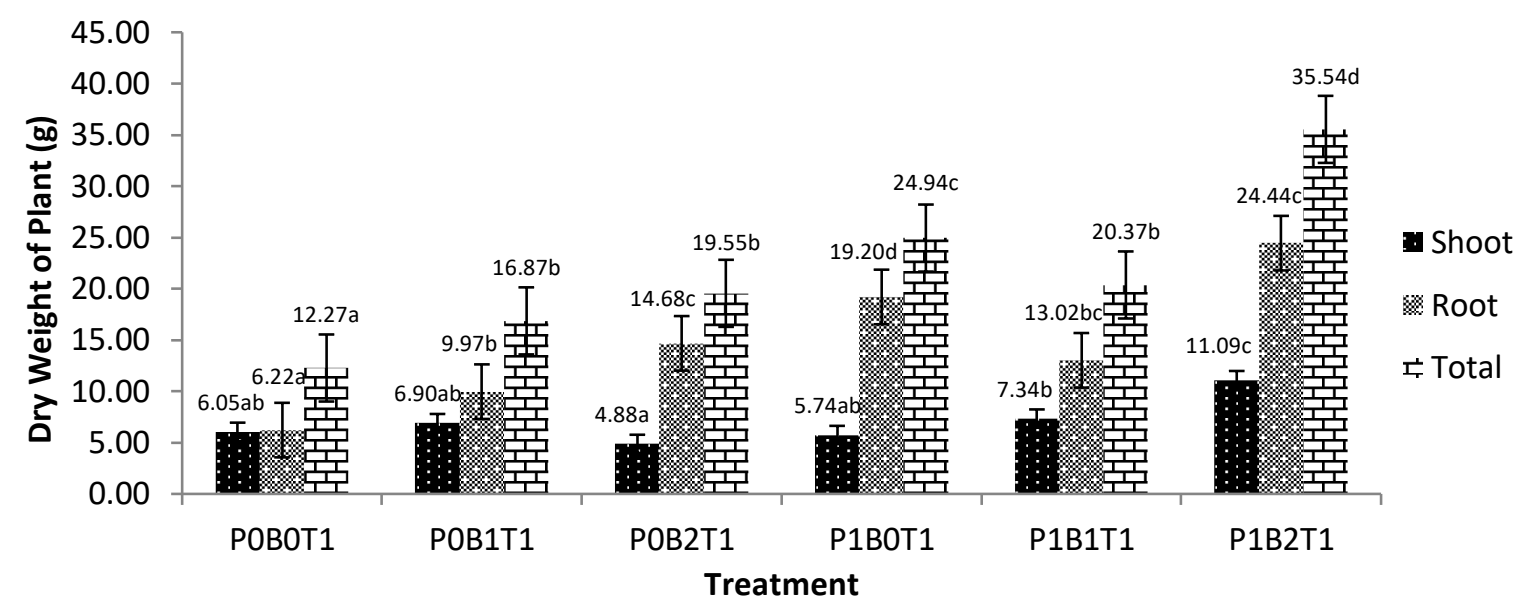

Figure 10. Effect of NPK fertilizer and chelator on dry weight of plant

Note: Mean followed with the same letter in the same column is not significantly different at $\alpha=0.05 ;{ }^{*}$ ) Table 1

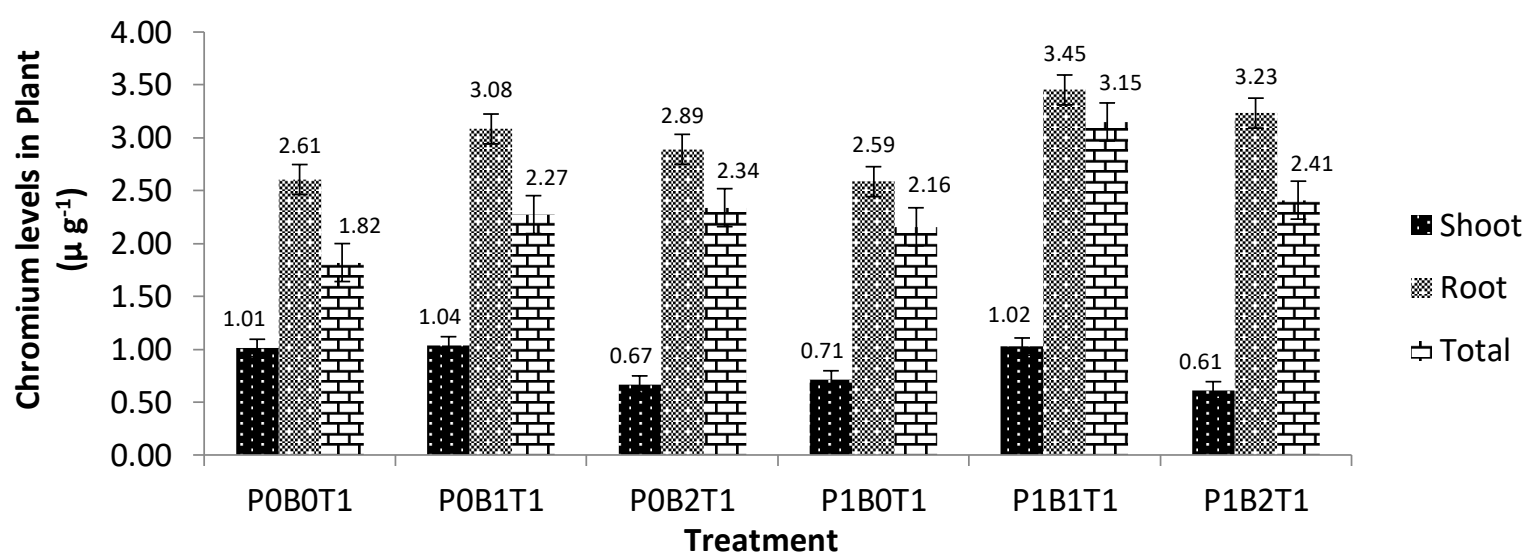

Figure 11. Effect of NPK fertilizer and chelator on chromium levels in plant Note: *) Table 1

Dry weight of Fimbristylis globulosa, the result of dry weight is shown in Figure 10. NPK fertilizer treatment, chelator treatment, and NPK fertilizer+chelator interaction had a significant effect $(p<0.05)$ on the total dry weight of plant based on ANOVA. T-test showed that total dry weight of plant was higher on P1 than T0. DMR test on chelator showed that B2 was the most effective on increasing the total dry weight of the plant compared to B1 and B0. Correlation test showed that the total dry weight of the plant was positively and very closely correlated to total chromium uptake in the plant $(r=0.896$ $p=0.000$ ). This means that the higher total dry weight of plant led to higher total chromium uptake in the plant.

\section{Chromium levels in Fimbristylis globulosa}

The analysis result of chromium levels in the plant could be seen in Figure 11. Chromium levels in the plant were obtained from total uptake divided by total biomass. ANOVA showed that all treatment gave no significant effect $(p>0.05)$ to chromium levels in the plant. Nevertheless, it was generally known that the chromium levels in the shoot, root, and total in the plant were higher in P1B1 with total chromium levels in plant up to $3.15 \mu^{-1}$ and has $1.33 \mu^{-1}$ difference compared to the control treatment which was the lowest treatment with total chromium levels $1.82 \mu^{-1}$. Correlation test showed that chromium levels in plant positively and closely correlated to chromium levels in the root $(r=0.509 p=0.031)$. The high levels of chromium in the root affected the increased total chromium levels in the plant. 


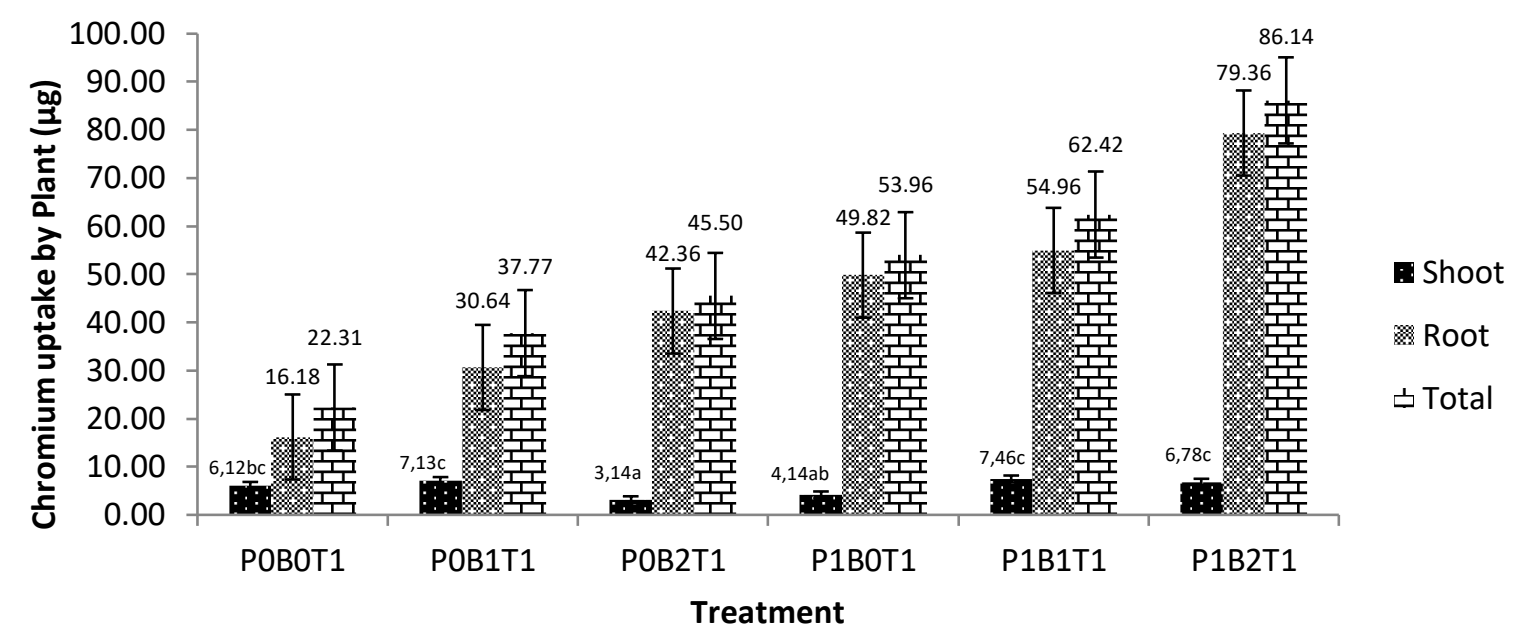

Figure 12. Effect of NPK fertilizer and chelator on chromium uptake in plant Note: Mean followed with the same letter in the same column is not significantly different at $\alpha=0.05$; ${ }^{*}$ ) Table 1

\section{Chromium uptake by Fimbristylis globulosa}

The analysis result of chromium uptake by the plant presented in Figure 12. ANOVA showed that NPK fertilizer treatment and chelator treatment had significantly affect chromium uptake by the plant $(p<0.05)$. Based on the DMR test, $B 2$ led to higher chromium uptake by plant compared to B0 and B1. Aside of that, Rhizobium $s p I_{3}$ also increased the chromium levels in plant and chromium uptake by the plant, as proved in the result of the analysis that $\mathrm{B} 1$ had higher chromium levels in plant and chromium uptake by plant than the BO. Correlation test showed that total chromium uptake by plant positively and very closely correlated to dry weight of root $(r=0.863$ $p=0.000)$, total dry weight $(r=0.896 p=0.000)$ and the number of tillers per clump $(r=0.868$ $p=0.000$ ). Total chromium uptake by plant also correlated positively and closely to dry weight of shoot $(r=0.690 \quad p=0.002)$ and removal effectivity $(r=0.608 p=0.007)$ and negatively correlated to chromium levels in soil $(r=-.610$ $p=0.007)$. That showed that the increased total chromium uptake by plant affected by the higher dry weight of root, shoot and the total plant also the number of tillers per clump. The higher total chromium uptake by plant led to higher removal effectivity (low chromium levels in soil).

\section{DISCUSSION}

The presence of plants could increase soil organic matter, led to higher soil $\mathrm{pH}$. According to Haynes \& Mokolobate (2001), the application of organic matter could increase soil $\mathrm{pH}$ through various mechanisms such as oxidation of organic acids and specific adsorption of organic molecules. Based on Lubis (2017), soil pH is very influential on plant growth and nutrient availability, resulting in increased plant height. CEC increased due to the addition of manure, according to the statement of McCauley et al. (2017), on land that had high organic matter will also have a high CEC. Soil CEC was able to improve nutrient accessibility for plants (Nesic et al., 2015), so that nutrient needed by the plant were fulfilled and led to increased plant height and number of tillers per clump.

The increased organic matter in this study was in accordance with the results of Takata et al. (2011) which shows that cow manure and plant residues could increase organic acids in the soil solution. According to McCauley et al. (2017), soil that had high 
organic matter will also have a high CEC and had a higher buffer. Organic matter had a negative charge while chromium and other heavy metals have a positive charge so that organic matter could form metal binding that helps plants to absorb metals from soil (Atanassova et al., 2012).

Rhizobium $s p I_{3}$ was capable to adapt to the chromium contaminated environment and grow well. According to Tangahu et al. (2011), soil microbes were found higher in the rhizosphere than in soils without plant roots. Plants emit root exudates which will be a nutrient for Rhizobium, according to Swamy et al. (2016) root exudates become intermediaries for plant and Microbes interactions by forming colonies on the roots and promoting the growth of the root. Based on Hidayati (2013), roots produced several exudates that involved in the rhizosphere interactions, where soil elements being transformed from the nonabsorbable form into an absorbable form. According to Pramono et al. (2012), rhizobacteria (in this study Rhizobium sp $I_{3}$ ) were able to increase the uptake of heavy metals by plant, to translocate heavy metals to other parts of the plant and to improved plant growth.

The highest reduction of chromium levels in the plant was found in P1B2T1 treatment (NPK fertilizer + manure + plant) and was the treatment with the highest removal effectivity. The removal may occur with the process of adsorption, that is a phenomenon that happens on the cell surface and absorption that involves the entire volume of material, also bioleaching where secretions produced by microbial metabolism such as low molecular weight organic acids can dissolve heavy metals and soil particle containing heavy metals minerals (Chen et al., 2010). Chromium toxicity on plant growth could be affected by the microorganism, organic compound, and root exudates. The increased plant height indicates that Fimbristylis globulosa grew well and no physiological abnormalities were found even in situations of chromium-contaminated soil, this was in line with the research of Ferina et al. (2017) which shows the same results. According to Sa'ad et al. (2011) F. globulosa, C. plastytylis, B. laevis, spinach (Amaranthus spp.), and mustard (B. juncea) can be used as phytoremediation agents that improved soil quality by absorbing heavy metals from the soil. The increased number of tillers per clump results in higher dry weight thus increased chromium uptake by plants. This was in accordance with research by Thanh et al. (2013) which shows that the increased biomass affects the increase in heavy metal uptake by plants. The higher chromium uptake by plant caused decreased chromium levels in soil so that the removal effectivity increased.

The high dry weight of plant according to Lubis (2017) due to the application of $\mathrm{N}$ and $\mathrm{P}$ fertilizers in the soil that can provide a lot of protein for plants, so that the growth of plant tissue and dry weight of plants increased. The increased chromium uptake by the plant was caused by the addition of manure that increased soil $\mathrm{pH}$ and organic matter so the mobility of heavy metals reduced and easily absorbed by the roots (Erinle et al., 2017). According to Nachimuthu et al. (2007), the increased biomass causes an increase in essential nutrient uptake. Pramono et al., (2013) stated that because chromium is a nonessential element for plants, chromium is absorbed together with essential elements such as sulfate through sulfate transport.

In general, the presence of Rhizobium sp $I_{3}$ as chelator increased chromium uptake by plants, showed from the high levels and uptake of chromium by plants in chelator of Rhizobium $s p I_{3}$ treatment compared to control treatment, with higher levels and uptake of chromium at the root than at the shoot. Rhizobium sp $I_{3}$ produced chromate reductase and organic compound that could transform the form of 
chromium (Rosariastuti, 2014). Chromium levels in plants that reached an average of 1.82-3.15 $\mu^{-1}$ indicate that the Fimbristylis globulosa had the ability to absorbed chromium beyond the threshold in plants set by FAO (2003) which is $1.30 \mathrm{mg} \mathrm{kg}^{-1}$.

\section{CONCLUSION}

Fimbristylis globulosa had high ability to absorb chromium and feasible to be used as phytoremediator. Chromium levels in the plant would increase when it combined with Rhizobium sp $I_{3}$. The highest removal effectivity was found in P1B2T1 treatment (NPK fertilizer + manure + plant) up to $71.90 \%$ indicated by the lowest chromium levels in soil $(1,22 \mathrm{mg} \mathrm{kg}$ $\left.{ }^{1}\right)$ and highest chromium uptake by the plant $(86.14 \mu \mathrm{g})$. For the future experiment, it is necessary to conduct similar research with a longer planting period to study the ability of heavy metals accumulation by Fimbristylis globulosa.

\section{REFERENCES}

Abatenh, E., Gizaw, B., Tsegaye, Z., \& Wassie, M. (2017). Application of Microorganisms in Bioremediation-Review. Journal of Environmental Microbiology, 1(1), 2-9.

Adji, S. S. (2006). Rehabilitasi Tanah Sawah Tercemar Natrium dan Logam Berat Melalui Pencucian Penggunaan Bahan Organik dan Bakteri. Bogor Agricultural University.

Atanassova, L., Velichkova, N., \& Teoharov, M. (2012). Heavy Metal Mobility in Soil Under the Application of Sewage Sludge. Bulgarian Journal of Agricultural Science, 18(3), 396-402.

BPS-Statistics of Karanganyar Regency. (2011). Karanganyar dalam Angka 2011 (Karanganyar in Figures 2011). (Integration Preparation and Dicemination Statistic Section, Ed.). Karanganyar, Indonesia: BPS-Statistics of Karanganyar Regency.

Chen, W. W., Yang, J. L., Qin, C., Jin, C. W., Mo, J. H., Ye, T., \& Zheng, S. J. (2010). Nitric
Oxide Acts Downstream of Auxin to Trigger Root Ferric-Chelate Reductase Activity in Response to Iron Deficiency in Arabidopsis. Plant Physiology, 154(2), 810-819.

Darini, M. T. (2012). Kajian Jarak Tanam dan Dosis Pupuk NPK Terhadap Sifat Agronomi Tanaman Mendong (Fimbrisqlis globulosa Retz. Kunth) serta Intensitas Kompetisi Gulma. Agro UPY, $4(1), 33-42$.

Erinle, K. O., Akande, T. Y., Urhie, J., \& Bitire, T. D. (2017). Effect of Manure Compost on Heavy Metal Translocation and BioConcentration Factors in Soils from an Old Municipal. New York Science Journal, 10(4), 51-59.

Ferina, P., Rosariastuti, R., \& Supriyadi. (2017). The Effectiveness of Mendong Plant (Fimbrystilis globulosa) as a Phytoremediator of Soil Contaminated with Chromium of Industrial Waste. Journal of Degraded and Mining Lands Management, 4(4), 899-905. 10.15243/jdmlm.2017.044.899

Food \& Agriculture Organization (FAO). (2003). Heavy Metal Regulations - Faolex Legal Notice No.66/2003. Retrieved May 8, 2018, from faolex.fao.org/docs/pdf/eri42405.pdf

Haynes, R. J., \& Mokolobate, M. S. (2001). Amelioration of Al toxicity and $\mathrm{P}$ deficiency in acid soils by additions of organic residues: A critical review of the phenomenon and the mechanisms involved. Nutrient Cycling in Agroecosystems, 59(1), 47-63.

Hidayati, N. (2013). Mekanisme Fisiologis Tumbuhan Hiperakumulator Logam Berat. Jurnal Teknik Lingkungan, 14(2), 75-82.

Indonesian Ministry of Environment. (2010). Himpunan Peraturan Lingkungan Hidup. Jakarta, Indonesia: Eko Jaya.

Lattanzi, P., Aquilanti, G., Bardelli, F., ladecola, A., Rosellini, I., Tassi, E., ... Petruzzelli, G. (2015). Spectroscopic Evidence of $\mathrm{Cr}(\mathrm{VI})$ Reduction in a Contaminated Soil by in Situ Treatment with Whey. Agrochimica, 59(3), 218-230.

Lubis, N. S. (2017). Pengaruh Pemberian 
Nitrogen dan Fosfor terhadap Berat Kering, Kandungan Nitrogen dan Fosfor Legum Tropis Merambat. Universitas Jambi.

McCauley, A., Jones, C., \& Olson-Rutz, K. (2017). Nutrient Management: Soil pH and Organic Matter (Module No.). Montana, USA: Montana State University. Nachimuthu, G., Velu, V., Malarvizhi, P., Ramasamy, S., \& Sellamuthu, K. M. (2007). Effect of Real Time N Management on Biomass Production, Nutrient Uptake and Soil Nutrient Status of Direct Seeded Rice (Oryza sativa L.). American Journal of Plant Physiology, 2(3), 214-220.

Nesic, L., Vasin, J., Belic, M., Ciric, V., Gligorijevic, J., Milunovic, K., \& Sekulic, P. (2015). The Colloid Fraction and CationExchange Capacity in the Soils of Vojvodina, Serbia. Ratarstvo $i$ Povrtarstvo, 52(1), 18-23.

Pramono, A., Rosariastuti, R., Ngadiman, \& Irfan, D. P. (2012). Peran Rhizobakteri dalam Fitoekstraksi Logam Berat Kromium pada Tanaman Jagung. Ecolab, 6(1), 1-60.

Pramono, A., Rosariastuti, R., Ngadiman, \& Irfan, D. P. (2013). Bacterial Cr(VI) Reduction and Its Impact in Bioremediation. Ilmu Lingkungan, 11(2), 120-131.

Rosariastuti, M. R. (2014). Peningkatan Serapan Kromium oleh Tanaman yang Diinokulasi Rhizobakteri. Gajah Mada University.

Sa'ad, N. S., Artanti, R., \& Dewi, T. (2011). Phyto-Remediation for Rehabilitation of Agricultural Land Contaminated by Cadmium and Copper. Indonesian Journal of Agriculture, 4(1), 17-21.
Silva, B., Figueiredo, H., Neves, I. C., \& Tavares, T. (2008). The Role of $\mathrm{pH}$ on $\mathrm{Cr}(\mathrm{VI})$ Reduction and Removal by Arthrobacter Viscosus. International Journal of Chemical and Molecular Engineering, 2(7), 70-73.

Swamy, M. K., Akhtar, M. S., \& Sinniah, U. R. (2016). Root Exudates and Their Molecular Interactions with Rhizospheric Microbes. In K. R. Hakeem \& M. S. Akhtar (Eds.), Plant, Soil and Microbes (Volume 2, pp. 59-77). Switzerland: Springer, Cham.

Takata, Y., Tani, M., Kato, T., \& Koike, M. (2011). Effects of Land Use and LongTerm Organic Matter Application on LowMolecular-Weight Organic Acids in an Andisol. Journal of Soil Science and Environmental Management, 2(10), 292298.

Tangahu, B. V., Abdullah, S. R. S., Basri, H., Indris, M., Anuar, N., \& Mukhlisin, M. (2011). A Review on Heavy Metals (As, Pb, and $\mathrm{Hg}$ ) Uptake by Plants through Phytoremediation. International Journal of Chemical Engineering, 1-31. 10.1155/2011/939161

Thanh, N. H., Le Ha, T. T., Viet Ha, C., Hung., N. D., Hung, P. Q., Kurosawa, K., \& Egashira, K. (2013). Uptake of $\mathrm{Pb}, \mathrm{Zn}$, and $\mathrm{Cu}$ by roots and shoots of fast growing plants grown in contaminated soil in Vietnam. Journal of Soil Science and Environmental Management, 4(6), 108-115. 10.5897/JSSEM11.009

Zhang, B. Y., Zheng, J. S., \& Sharp, R. G. (2010). Phytoremediation in Engineered Wetlands: Mechanisms and Applications. Procedia Environmental Sciences, 2, 1315-1325.

10.1016/j.proenv.2010.10.142 